ISSN: 2146-3042

DOI: $10.25095 /$ mufad.625767

\title{
Dövizdeki Volatilitenin Takipteki Krediler Üzerine Etkisi: Türkiye Örneği
}

Erkan POYRAZ*

Osman Emre ARLI **

\section{$\ddot{O Z Z E T}$}

Bu çalışmada yabancı para birimlerinin; Türkiye bankacıllk sektörünün, takibe düşmüş alacaklarına etkisi ampirik olarak araştırılmıştır. Bu kapsamda Ocak 2008 - Ağustos 2018 dönemlerine ait Türkiye bankacılık sektörü bilançosundan "takipteki alacaklar" hesabı ile USD (Amerikan Doları), GBP (Büyük Britanya Poundu) ve JPY (Japon Yeni) para birimlerinin Türk Lirası karşıllkları için; genişletilmiş Dickey-Fuller testi, Johansen eşbütünleşme testi ve Granger nedensellik testi yapılmıştır. Yapılan testlerin sonuçlarına göre USD ile takipteki krediler arasında uzun dönemli ilişki görülmüs, USD'nin takipteki kredileri etkilediği saptanmıştır. GBP'nin takipteki krediler ile uzun dönemli net bir ilişkisi ortaya koyulamamış; fakat GBP'nin takipteki kredilerin nedeni konumunda olduğu görülmüşürr. JPY'nin ise takipteki krediler ile uzun dönemli bir ilişkisi olmadiğ̀ görülmüş̧ür.

Anahtar Kelimeler: Takipteki Krediler, Johansen Eşbütünleşme, Granger Nedensellik

JEL Sinıflandırması: G21, G32

\section{Volatility In Currency The Effect Of Non-Performing Loans: In Turkey}

\section{ABSTRACT}

In this study, foreign currencies, Turkey of the banking sector, the effects of receivables declined to follow are empirically investigated. In this context January 2008 - August 2018 period, the balance sheet of the banking sector in Turkey "NPLs" with accounts in USD (United States Dollar), GBP (Great Britain Pound) and JPY (Japanese Yen) currency provisions of the Turkish Lira; extended Dickey-Fuller analysis, Johansen cointegration analysis and Granger causality analysis. According to the results of the analysis, a long-term relationship was observed between USD and nonperforming loans. The Bank's long-term, clear relationship with non-performing loans has not been established; however, it was observed that the cause of the non-performing loans was in the position. It is observed that JPY has no long-term relationship with non-performing loans.

Keywords: Non-performing Loans, Johansen Cointegration, Granger Causality.

Jel Classification: G21, G32

Makale Gönderim Tarihi: 15.01.2019

Makale Kabul Tarihi: 12.02.2019

Makale Türü: Araştırma Makalesi

\footnotetext{
* Prof. Dr., Muğla Sitkı Koçman Üniversitesi, İktisadi ve İdari Bilimler Fakültesi, poyraz@mu.edu.tr, Orcid ID: 0000-0002-6442-4705.

** Öğr. Gör., Muğla Sıtkı Koçman Üniversitesi, Muğla Meslek Yüksekokulu, emrearli@mu.edu.tr, Orcid ID: 0000-0002-7756-9372.
} 


\section{GİRIŞ}

Ekonomide önemli bir işleve sahip olan bankalar, tasarruf fazlası olanlar ile tasarruf açığı olanlar arasında fon akışı sağlamaktadır. Bu işlevi, belli bir ücret karşılığı (faiz, komisyon, kar payı vb.) vermiş olduğu kredilerle gerçekleştirmektedir. Bankaların faaliyetlerini devam ettirebilmeleri ve kârlılıklarını arttırabilmeleri için vermiş oldukları kredilerin geri dönüşlerini sağlamaları gerekmektedir. Kredilerde geri dönüşlerin sağlanamaması bankacılık sektöründe ve dolayısı ile ekonomide ciddi riskleri beraberinde getirebilir.

01.11.2006 tarihli ve 26333 Sayılı Resmi Gazete'deki “Bankalarca Kredilerin Ve Diğer Alacakların Niteliklerinin Belirlenmesi Ve Bunlar İçin Ayrılacak Karşılıklara İlişkin Usul Ve Esaslar Hakkında Yönetmelik"te "Donuk Alacaklar" ile ilgili 5. Maddesinde; "Borçlusunun aynı banka tarafından verilmiş birden çok kredisinin mevcut bulunması ve bu kredilerden herhangi birinin yapılan sınıflandırma gereği donuk alacak olarak kabul edilmesi durumunda, söz konusu borçlunun bankadan kullanmış olduğu tüm kredileri donuk alacak olarak aynı grupta sınıflandırılır". Yine aynı madde devamında, vadesinden veya ödenmesi gereken tarihten itibaren doksan günden fazla geçen krediler de "Donuk Alacak" sinıflandirması yapılmaktadır. (Resmi Gazete, 2006)

Donuk alacaklar, diğer bir ifade ile takipteki krediler, bankalar için bazı riskleri beraberinde getirmektedir. Bunlardan en önemlileri kârlılık ve likidite riskidir. Geri ödenmeyerek takibe düşen krediler için bankalar belirli oranlarda karşılık ayırmakta ve gider olarak göstererek kârlılı̆̆ını etkilemektedir. Vadesinde ödenmesi beklenen krediler ise geri dönüşü zamanında sağlanamadığı için bankalar açısından likidite riski yaratmaktadır.

Kredi portföy kalitesindeki bozulma banka genel performansını etkileyebilir, aynı zamanda banka sermayesini tehlikeye atabilir ve iflasa yol açabilir. Ayrıca, bankacılık sisteminin önemli bir kısmında takipteki kredilerin artması durumunda, tüm sektörün finansal istikrarı tehdit edilmektedir. Bankaların ek kredi riski kabul etmedeki isteksizliği reel ekonomi üzerinde olumsuz etkiler yaratmaktadır. Böylece, takipteki kredilerin faktörlerini anlamak bankalar ve düzenleyiciler için değerlidir. (Ćurak vd., 2013: 45)

Takipteki krediler bankacılık sektörünü etkilediği kadar, makroekonomik anlamda da etkilerinden söz edilmektedir. 2009 yılında Amerika Birleşik Devletlerinde yaşanan kriz ve başta ABD olmak üzere dünya ekonomisine yansıması örnek olarak gösterilebilmektedir. Özellikle ABD' de taşınmazlar sektöründe oluşan balonun ve gayrimenkule verilen kredilerin geri ödemesinde yaşanılan olumsuzluklar küresel bir krize neden olmuştur. (Akgüç, 2009: 7)

Bankacılık sektöründe geri ödenmeyerek takibe dönüşen alacaklar, ekonominin geneli üzerine etkileri olduğu varsayılmaktadır. $\mathrm{Bu}$ nedenle takipteki krediler makroekonomik açıdan önemli bir gösterge niteliği taşımaktadır. Son dönemde takipteki krediler ile ilgili yapılan çalışmalar bankacılık sektöründeki takipteki krediler üzerinde etki eden faktörleri, hangi değişkenlerin hangi yönde etkilediği noktasındadır. Bu araştırmanın amacı çerçevesinde ikinci bölümde takipteki kredilere etki eden faktörler üzerine bir literatür çalışması yapılmıştır. Üçüncü bölümde dövizdeki oynaklık ile takipteki krediler arasındaki kısa ve uzun dönemli ilişkiye bakmak için öncelikle genişletilmiş Dickey-Fuller testi yapılarak birim 
köklere bakılmış daha sonra Johansen eşbütünleşme testi ve Granger nedensellik testi yapılmıştır. Son bölümde test sonuçları yorumlanmıştır.

\section{LITERATÜR TARAMASI}

Takipteki krediler literatürü incelendiğinde; genel görüşün, takipteki kredilerin önemli bir makroekonomik gösterge olabileceği ve ekonominin geneli üzerinde bir takım etkiler yaratabileceği yönündedir. Bu açıdan takipteki krediler ile çeşitli makroekonomik göstergeler (büyüme, gayri safi yurtiçi hasıla, enflasyon, faiz, üretim endeksi ve bazı borsaların endeksleri, işsizlik, bazı döviz kurları vb.) arasındaki ilişkiler incelendiği ve araştırmaların takipteki kredilerin makroekonomik belirleyicileri üzerine yoğunlaştığg görülmektedir.

Keeton ve Morris' in (1987) 10. FED bölgesinde yaklaşık 2.500 bankanın örneklemini kullanarak yaptıkları çalışmada takipteki kredilerin nedenlerini araştırmışlardır. Yerel kayıplardaki değişimin önemli bir kısmının yerel ekonomik koşullardaki farklılıklara, tarım ve enerji gibi belirli endüstrilerin olağandışı kötü performanslarında kaynaklandığına işaret etmektedir.

Berger ve DeYoung (1997) takipteki krediler ile bankaların sermaye performansları arasında Granger nedensellik testi yapmışlar ve aralarında ters yönlü bir ilişkiyi tespit etmişlerdir.

Ćurak ve arkadaşlarının (2013) Güneydoğu Avrupa bankacılık sisteminde yer alan 10 ülkedeki 69 banka üzerine yaptıkları çalışmada, makroekonomik verilerin ve bankacılıkla ilgili bir takım değişkenlerin panel veri testi ile takipteki krediler üzerindeki etkisi araştırılmıştır. Buna göre ekonomideki düşük büyüme, yüksek enflasyon ve yüksek faiz oranı takipteki kredileri pozitif yönde etkilemekte, ayrıca kredi riski, banka büyüklügüu, banka performansı ve ödeme gücü gibi değişkenlerden de etkilendiğini ortaya koymuşlardır.

Mileris (2012) nin yaptığı çalışmada 22 Avrupa Birliği üyesi ülkenin bankacılık sektörü ele alınmış, şüpheli ve takipteki kredilerle ilgili tahmin modeli geliştirilmiştir. Elde ettiği sonuçlara göre takipteki kredilerin; GSYİH, enflasyon, faiz oranları, para arzı, sanayi üretim endeksi, cari işlemler dengesi gibi pek çok makroekonomik değişken ile ilişkisi olduğunu ortaya koymuştur. Takipteki kredilerin ekonomi için önemli bir unsur olduğunu ifade etmiştir. Araştırmada geliştirilen model, ortalama\% 98,06 doğrulukta bankalardaki şüpheli ve tahsili gecikmiş kredilerin yüzdesini tahmin etmeyi mümkün kılmıştır.

Castro (2013) Yunanistan, İrlanda, Portekiz, İspanya ve İtalya için 1997-2011 yılları arasında bir panel veri testi gerçekleştirmiş; bankacılık kredi riskinin makroekonomik ortamdan önemli ölçüde etkilendiği sonucuna ulaşmıştır. GSYİH büyümesi, hisse senedi fiyat endeksleri ve konut fiyatlarının azalması ve artması durumunda, kredi riskinin arttığı; işsizlik oranı, faiz oranı ve kredi büyümesi arttığında; reel döviz kuru oranının olumlu yönde etkilendiği; ayrıca son mali kriz döneminde kredi riskinde önemli bir artış olduğu gözlemlenmiştir.

Ranjan ve Dhal (2003) Hindistan'daki kamu bankaları üzerine yaptıkları araştırmada; kredi büyüklüğü değişkenlerinin, banka büyüklüğü ve makroekonomik şoklar nedeniyle bankaların takipteki kredileri üzerinde önemli etkiye sahip olduğunu göstermiştir. Ayrıca, 
banka büyüklüğünün alternatif ölçütleri bankanın takipteki kredileri üzerinde farklı etkilere neden olabilmektedir.

Klein (2013) Orta, Doğu ve Güneydoğu Avrupa ülkeleri üzerinde takipteki kredilerin belirleyicileri ve makroekonomik performansa etkilerini incelemek için VAR modelini kullanmıştır. Araştırmaya 16 Avrupa Birliği Ülkesi katılmış 1998-2011 yılları arasındaki panel verileri analiz edilmiştir. Büyüme oranı, enflasyon ve işsizlik oranının takipteki kredileri etkilediğini ortaya koymuştur.

Anastasiou ve arkadaşlarının (2016) yaptıkları çalışmada Avrupa ülkeleri bankacılık sektörü araştırmaya konu olmuş, takipteki kredileri etkileyen faktörleri panel veri ve VAR modeli kullanarak hem makroekonomik değişkenleri hem de bankacılığa özgü değişkenleri analiz etmiş̧lerdir. Araştırmalarına göre takipteki krediler 2008 yılından sonra artış göstermiştir. Bunun nedeni olarak kötü giden işsizlik, büyüme ve vergiler başta olmak üzere kötü giden makroekonomik unsurlar olduğunu tespit etmişlerdir.

Yüksel (2016) çalışmasında Türkiye'deki bankaların takipteki kredi oranlarını belirleyen faktörleri tespit etmeyi amaçlamıştır. USD kurundaki artışın bankaların takipteki kredi oranlarını arttırdığı, faiz gelirleri ile takipteki kredilerin arasında negatif yönlü bir ilişkinin olduğu ve büyüme oranı ile takipteki krediler arasında ters yönlü bir ilişki olduğu saptanmıştır.

Yağcılar ve Demir (2015) panel veri analizi ile yaptıkları çalışmada Türkiye'de faaliyet gösteren 26 ticari banka verilerini incelemişlerdir. Borsada işlem görme, ölçek, kredi/mevduat oranı, likidite ve aktif karlılığı değişkenlerinin takipteki krediler ile negatif yönlü, büyüme, faiz oranları, yabancı bankalar ve sermaye yeterliliği rasyosu ile pozitif yönlü ilişki içinde olduğunu belirlemişlerdir.

Demirel (2015) bankacılık sektörünü etkileyen değişkenlerin tahmini için VAR modeli kullanarak makroekonomik şokların takipteki krediler üzerinde etkilerini araştırmıştır. Ayrıca eş bütünleşme analizi kullanarak değişkenler arasındaki uzun dönemli ilişkileri ele almıştır. Ulaştı̆̆1 sonuçlara göre; sanayi üretimi, ekonomik büyüme, borsada yaşanan kayıplar ile takipteki krediler arasında negatif yönlü, cari açık ile takipteki krediler arasında pozitif yönlü ilişkinin varlığından söz edilmiştir.

Abdioğlu ve Aytekin (2016) yaptıkları çalışmada, bir önceki dönemdeki takipteki kredi oran1, net faiz marjı, sermaye yeterliliği ve ödeme gücü oranı ile takipteki krediler arasında negatif yönlü, krediye uygulanan faiz, kredi/mevduat oranı, etkinsizlik ve faaliyet etkinliği değişkenleri ile takipteki krediler arasında pozitif yönlü ilişkiye işaret etmektedirler.

Tekşen ve Çelik (2018) yaptıkları çalışmada kredi türleri ile takipteki kredilerin ilişkisini araştırmışlardır. Konut ve ticari taşıt kredileri ile takipteki krediler oranı arasında negatif, taşıt kredileri ile takipteki krediler oranı arasında pozitif yönde bir ilişki tespit etmişlerdir. Ayrıca enflasyon, önceki dönem takipteki krediler oranı ve aktif büyüklüğü değişkenlerinin de takipteki krediler oranı üzerinde anlamlı ve pozitif; kriz değişkeninin ise anlamlı ve negatif bir etkisinin olduğu sonucuna varmışlardır. 
Genç ve Şaşmaz (2016) Hatemi-J eş bütünleşme testi yaparak takipteki ticari kredilerin belirleyici makroekonomik faktörlerini tespit etmeye çalışmışlardır. GSYİH, BIST100 endeksi, ticari kredi faiz oranları ve reel döviz kurlarının takipteki krediler üzerinde belirleyici faktör olduğu sonucuna ulaşmışlardır. BIST-100 endeksinin takipteki ticari kredi oranlarını negatif güçlü yönde etkilediğini, reel döviz kurunun ise pozitif güçlü yönde etkilediğini tespit etmişlerdir.

Gökçe ve Sarıtaş (2017) çalışmalarında döviz kurlarındaki değişim, özel sermayeli bankaların bilançosundaki kalemlere etkisi olacağı hipotezini geliştirmişlerdir. Buna göre döviz kurlarındaki değişimden takipteki kredilerin aynı yönlü etkilendiğini tespit etmişlerdir.

Tanınmış Yücememiş ve Sözer (2011) takipteki kredi oranlarını aylık bazda ekonomik verilerle tahmin etmeye çalışmışlar, kurdukları modelde geçmiş dönem performansının gerçekleşen değerle örtüştüğünü görmüşlerdir. Buna göre takipteki kredilerin, geçmiş dönem performansından etkilendiğini tespit etmişlerdir. Aynı zamanda takipteki krediler oranının, TL değerinden ve sanayi üretiminden bir dönem gecikmeli etkilendiğini saptamışlardır.

\section{DÖVIZDEKI VOLATILITENIN TAKIPTEKİ KREDILER ÜZERINNDEKİ ETKİSI}

Dövizdeki yaşanan dalgalanmanın Türk Bankacılık Sektörünün takipteki kredileri üzerindeki etkisinin araştırılması amacıyla; Bankacılık Düzenleme ve Denetleme Kurumu'nun (BDDK) Ocak 2008 - Ağustos 2018 dönemlerine ait Türk Bankacılık Sektörü Aylık Bülteni'nden, bankacılık sektörü bilançoları incelenmiştir. İlgili bilançoda "Takipteki Alacaklar" hesabından 128 aylık döneme ait veriler araştırmaya dahil edilmiştir. 2008 yılı ve öncesi bankaların takipteki alacaklara ilişkin verilerine aylık bazda ulaşılamamıştır. Bu nedenle 2008 yılı Ocak ayı başlangıç olarak alınmış, çalışmanın başladığı 2018 Eylül ayında son olarak Ağustos ayı verilerine ulaşılmış bu nedenle Ağustos 2018'e kadar olan veriler çalışmada ele alınmıştır.

Çalışmada yabancı para birimleri bakımından "Society for Worldwide Interbank Financial Telecommunication" un (SWIFT) Aralık 2017 raporuna göre dünyada en çok dolaşımda olan para birimlerinden ilk dört tanesi seçilmiştir. (Şekil 1) Fakat Avrupa Birliği Para Birimi (EUR) araştırma modelinde istatistiksel olarak anlamsız bulunduğu için araştırmaya dahil edilmemiştir. Buna göre Amerikan Doları (USD), İngiliz Sterlini(GBP) ve Japon Yeni (JPY) araştırmaya dahil edilmiştir. Araştırmada belirtilen yabancı para birimlerinin, Türk Lirası (TRY) cinsinden değerleri alınmıştır. Türkiye Cumhuriyet Merkez Bankasının (TCMB) gösterge niteliğindeki kurları aylık olarak "Elektronik Veri Dağıtım Sistemi”nden (EVDS) alınmıştır. 


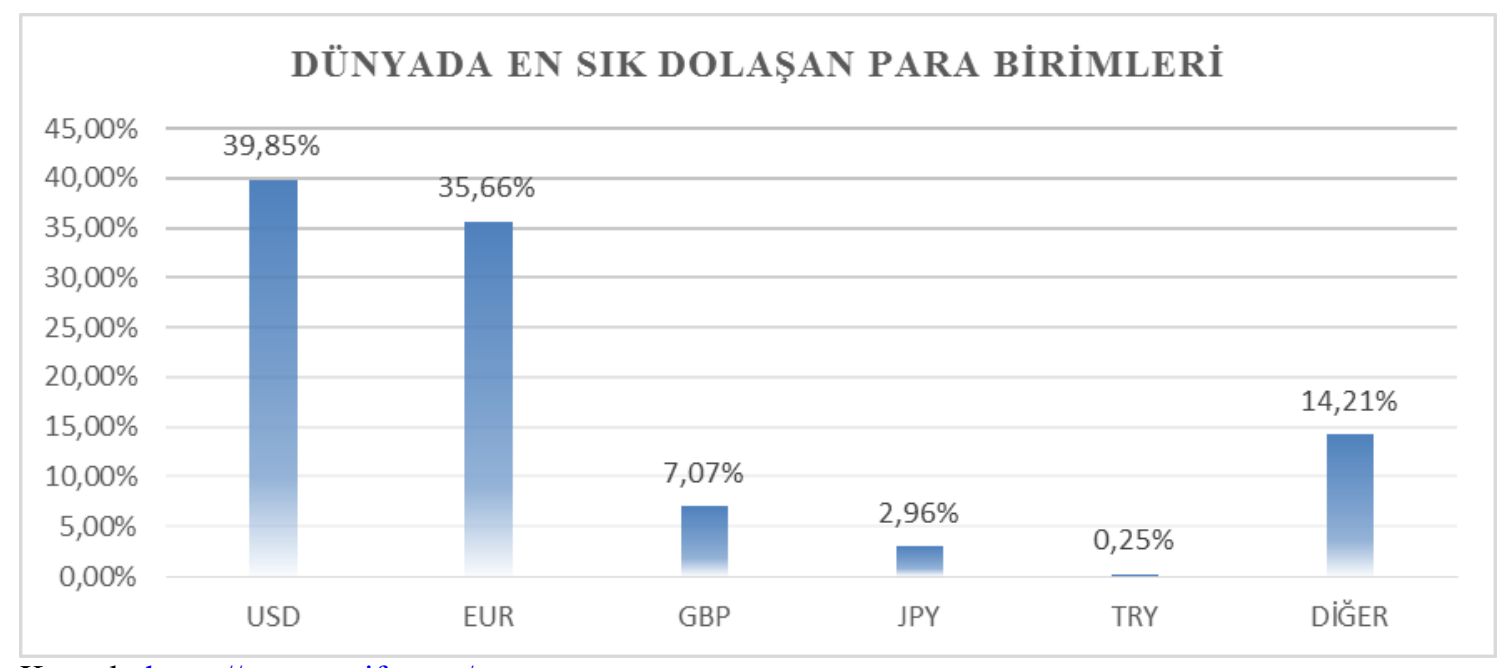

Kaynak: https://www.swift.com/

Şekil 1. 2017 Y1lı Swift Raporuna Göre Dünya Üzerinde En Sık Dolaşan Para Birimleri

\section{a. Araştırmanın Amacı ve Yöntemi}

$\mathrm{Bu}$ çalışmada dövizdeki oynaklığın takipteki krediler üzerindeki etkisinin ampirik olarak araştırılması amaçlanmıştır. Takipteki kredileri kısa ve uzun dönemde etkilediği düşünülen para birimlerinin Türk Lirası cinsinden değerleri ele alınmıştır. Ocak 2008-Ağustos 2018 dönemine ait 128 aylık veri üzerinden dövizdeki dalgalanmanın takipteki krediler üzerindeki etkisinin araştırılması amacıyla zaman serisi testi gerçekleştirilmiştir. Bu nedenle çalışmada takipteki krediler bağımlı değişken ve tek tek döviz kurları; USD, GBP ve JPY bağımsız değişken olarak ele alınmıştır. Araştırmada kısa ve uzun dönem ilişkisini inceleyen Johansen eşbütünleşme testi ve Granger nedensellik testleri kullanılmıştır. Araştırmada analizler E-Views 9.0 programı yardımıyla yapılmıştır.

Zaman serisi analizinin en önemli varsayımı serilerin olmasıdır. Zaman serisi verilerini kullanarak iki değişken arasında istatistiksel bakımdan anlamlı bir ilişki bulunabilir. Ancak bu ilişki ortak bir trendin varlığından kaynaklanabilir. Bu nedenle serilerin durağanlaştırılması gerekmektedir (Göktaş vd., 2018: 1)

Araştırmada takipteki krediler ile döviz kurları verileri arasında ölçek farklılığı ve farklı varyanslılık olduğu için serilerin logaritması alınmıştır. Daha sonra logaritması alınmış serilerin "Genişletilmiş Dickey-Fuller(ADF)" testi yapılarak serilerin durağanlığına bakılmış, durağan olmayan serilerde birim kökler ortadan kaldırılmış ve seriler durağan hale getirilmiştir.

\section{Genişletilmiş Dickey-Fuller (ADF) Birim Kök Testi}

Zaman serisinin ortalamasında ve varyansında sistematik bir değişme yoksa ve eğer düzenli periyodik değişmeler ortaya çıkmıyorsa, seri durağandır denir (Gujarati., 1995: 711713). Zaman serisinin durağan olmaması, serinin trend ve sabit terim içerdiğini gösterir. Serinin durağanlığının tespiti için çeşitli testler geliştirilmiştir. Bunlardan biri olan "Genişletilmiş Dickey-Fuller" (ADF) birim kök testi, serinin trend ve sabit terim içerip 
içermediğinin tespit edilmesinde kullanılabilir. ADF birim kök testinde aşağıdaki 3 denklem kullanılır;

$$
\begin{gathered}
\Delta Y_{t}=\delta Y_{t-1}+\sum_{i=2}^{\rho} \beta_{i} \Delta Y_{t-i}+\epsilon_{t} \\
\Delta Y_{t}=\alpha+\delta Y_{t-1}+\sum_{i=2}^{\rho} \beta_{i} \Delta Y_{t-i}+\epsilon_{t} \\
\Delta Y_{t}=\alpha+\delta Y_{t-1}+\sum_{i=2}^{\rho} \beta_{i} \Delta Y_{t-i}+\gamma T+\epsilon_{t}
\end{gathered}
$$

ADF testinde sabit terim ve stokastik trendin olmadığı bir rassal yürüyüşs sürecini, sabit terimin olduğu bir rassal yürüyüş sürecini, hem sabit terim hem de stokastik trendin olduğu rassal yürüyüşs sürecini tanımlamaktadır. Bu 3 denklemde de $\delta=0$ yokluk hipotezi test edilir. Yokluk hipotezi reddedilip $\delta<0$ hipotezi kabul edilirse $\mathrm{Y}_{\mathrm{t}}$ serisi durağan olur (Malik vd., 2010: 21-31). Bir zaman serisinin durağan hale getirebilmek için iki yöntem vardır. Birincisi serinin farklarının alınması, diğer yöntem de deterministik trendin elimine edilmesidir (Sevütekin ve Nargeleçekenler, 2005: 206).

\section{Johansen Eşbütünleşme Testi}

Johansen (1988) eşbütünleşme testinde aynı dereceden durağan olan serilerin denklem sistemi, değişkenlerin düzey değerleri ve gecikme uzunluklarının yer aldığı VAR (Vector Auto Regression) analizine dayanmaktadır (Tar1 ve Yıldırım, 2009: 100). Johansen eşbütünleşme testi 2 amaca ulaşmak için kullanılır. Değişkenler arasında en fazla sayıda eşbütünleşme vektörünü belirlemek ve uyarlama hızı katsayılarının en çok olabilirlik tahminlerini elde etmektir (Göktaş vd., 2018: 43). Johansen eşbütünleşme testinde gecikme uzunluğu belirlemede birden çok kritere bakılır. Akaike bilgi kriteri (AIC), Schwarz bilgi kriteri (SC), Hannan-Quinn bilgi kriteri (HQ) ve Son Tahmin Hatas1 kriteri (FPE) kullanılabilir.

Johansen testi, ADF testi gibi yüksek dereceden bir AR süreçle ifade edilmektedir. Bir VAR modeli kullanılarak $X_{t}$ değişken vektörünün gecikmeli değerini modele dahil etmektedir (Göktaş vd., 2018: 44).

$$
X_{t}=\Pi_{1} X_{t-1}+\ldots+\Pi_{k} X_{t-k}+\epsilon_{t}(t=1,2, \ldots, T)
$$

\section{Granger Nedensellik Testi}

Granger nedensellik testi iki değişken arasındaki nedensellik ilişkinin varlığını ve ilişkinin yönünü test etmek için kullanılır. Granger nedenselliği şu şekilde tanımlamıştır 'Y'nin öngörüsü, X'in geçmiş değerleri kullanıldığında, X'in geçmiş değerleri kullanılmadığı duruma göre daha başarılı ise X, Y'nin Granger nedenidir". (Gujarati, 2009: 620). Test aşağıdaki gibi VAR sisteminin tahminine dayanmaktadır (Göktaş vd., 2018: 58). 


$$
\begin{gathered}
X_{t}=\sum_{i=1}^{p} \alpha_{i} Y_{t-i}+\sum_{j=1}^{p} \beta_{j} X_{t-j}+\epsilon_{1 t} \\
Y_{t}=\sum_{i=1}^{q} \gamma_{i} Y_{t-i}+\sum_{j=1}^{q} \delta_{j} X_{t-j}+\epsilon_{2 t}
\end{gathered}
$$

Burada hataların $\in_{1 t}$ ve $\in_{2 t}$ ilişkisiz olduğu varsayılmaktadır. Değişkenlerin her biri bağımlı değişken olarak modelin sol tarafında yer almakta ve diğer değişkenin gecikmeleriyle model kurulmaktadır (Göktaş vd., 2018: 58).

\section{Verilerin Analizi}

Araştırmada öncelikle takipteki krediler üzerinde etkisi olduğu düşünülen döviz kurları ile bir model kurulmuştur. Buna göre;

$$
Y_{i}=C+x d_{1 i}+y d_{2 i}+z d_{3 i}+\epsilon_{i}
$$

Modelde yer alan $\mathrm{Y}$, takipteki kredileri, $\mathrm{C}$, modele etki eden sabit terimi, $\mathrm{d}_{1}, \mathrm{~d}_{2}, \mathrm{~d}_{3}$ sırası ile USD, GBP ve JPY'yi, x, y ve z katsayılarını, $\epsilon$ ise hata terimini göstermektedir. Takipteki kredileri etkilediği düşünülen değişkenlerin oluşturduğu model değerleri Tablo 1 'de verilmiştir. EUR değişkenin de dahil edildiği modelde, GBP ve JPY de istatistiksel olarak anlamsız hale gelmektedir. Bu nedenle EUR değişkeni modelden çıkarılarak analize devam edilmiştir.

Tablo 1. Araştırma Modeli Değerleri

\begin{tabular}{|c|r|r|r|r|}
\hline $\begin{array}{c}\text { Bă̆ımsız } \\
\text { Değişkenler }\end{array}$ & \multicolumn{1}{|c|}{ Katsayısı } & Standart Hatası & t-İstatistik Değeri & Olasılık Değeri \\
\hline $\log (\mathbf{U S D})$ & 2.133741 & 0.227830 & 9.365491 & 0.0000 \\
\hline $\log (\mathbf{G B P})$ & -0.648494 & 0.215680 & -3.006740 & 0.0032 \\
\hline $\mathbf{L o g}(\mathbf{J P Y})$ & -0.285789 & 0.128430 & -2.225256 & 0.0279 \\
\hline $\mathbf{C}$ & 9.645691 & 0.143812 & 6.707174 & 0.0000 \\
\hline
\end{tabular}

Verilerin analiz edilmesinde “Johansen Eşbütünleşme” ve "Granger Nedensellik Testi" uygulamadan önce Genişletilmiş Dickey-Fuller (ADF) testi yapılarak birim köklerine bakılmıştır. Tablo 2'de değişkenlerin olasılık değerlerinin 0,05'in altında olmadığı için birim kök olduğunu ve değişkenlerin durağan hale getirilmesi gerektiği görülmüştür. 
Tablo 2. Genişletilmiş Dickey-Fuller Testi

\begin{tabular}{|c|c|}
\hline Değişkenler & Olasılık Değerleri \\
\hline $\log ($ Takipteki Krediler $)$ & 0.9049 \\
\hline $\log (\mathrm{USD})$ & 0.9997 \\
\hline $\log (\mathrm{GBP})$ & 0.9998 \\
\hline $\log (\mathrm{JPY})$ & 0.9857 \\
\hline
\end{tabular}

Tablo 3'te görüldüğü gibi trende ve sabit terime sahip serilerin birinci farkları alınmış ve birim kökler ortadan kaldırılmıştır.

Tablo 3. Birinci Farkları Alınmış Serilerin Birim Kök Testleri

\begin{tabular}{|c|c|}
\hline Değişkenler & Olasılık Değerleri \\
\hline $\log ($ Takipteki Krediler $)$ & 0.0000 \\
\hline $\log ($ USD $)$ & 0.0000 \\
\hline $\log (\mathrm{GBP})$ & 0.0000 \\
\hline $\log (\mathrm{JPY})$ & 0.0000 \\
\hline
\end{tabular}

Tablo 3 incelendiğinde olasılık değerlerinin 0,05 değerinin altında olduğu, serinin birinci farklarının alınarak birim köklerin ortadan kaldırıldığı ve serinin durağan hale geldiği görülmektedir. Durağanlığı sağlanan serilerin kısa ve uzun dönem ilişkilerine bakmak amacıyla Johansen (1988) eşbütünleşme testi uygulanmıştır.

Johansen eşbütünleşme ve Granger nedensellik testleri, takipteki krediler bağımlı değişken olacak şekilde her döviz kuru ile karşılaştırılmıştır. Buna göre; takipteki kredilerUSD, takipteki krediler-GBP, takipteki krediler-JPY şeklinde değişkenler arasında analizler yapılmıştır.

Johansen eşbütünleşme testine başlamadan önce serilerin gecikme uzunluklarına bakılmalıdır ve en uygun gecikme sayısı belirlenmelidir. (Tarı ve Y1ldırım, 2014: 101) Bu amaçla Akaike Bilgi Kriteri (AIC) ile Schwarz Bilgi Kriterine (SC) gibi kriterlere bakılabilir (Vurur ve Özen, 2013: 125). Veriler aylık olduğu için maksimum gecikme uzunluğu 1'den başlayarak 12'ye kadar hesaplanmıştır. Buna göre takipteki krediler-USD Akaike bilgi kriterine göre gecikme uzunluğu 3. dönem, takipteki krediler-GBP için gecikme uzunluğu Akaike bilgi kriterine göre 3. dönem ve takipteki krediler-JPY için Akaike bilgi kriterine göre gecikme uzunluğu 3. dönem olduğu görülmüştür.

Gecikme uzunlukları belirlenen zaman serilerinin Johansen Eşbütünleşme testine geçilmiştir. Takipteki krediler ile USD arasında Johansen Eşbütünleşme testleri yapılmış ve sonuçları Tablo 4 ve Tablo 5 'te verilmiştir. 
Tablo 4. Takipteki Krediler - USD Johansen Eşbütünleşme Testi (İz Değer)

\begin{tabular}{|c|c|c|c|c|}
\hline Hipotezler & Özdeğer & İz İstatistik Değer & \%5 Kritik Değer & Olasılık Değeri \\
\hline $\mathrm{H}_{0}$ & 0.113556 & 17.53846 & 15.49471 & 0.0243 \\
\hline $\mathrm{H}_{1}$ & 0.020685 & 2.591888 & 3.841466 & 0.1074 \\
\hline
\end{tabular}

Tablo 4'te $\mathrm{H}_{0}$ hipotezi için iz istatistik değerinin \%5'lik kritik değerden büyük olduğu görülmektedir. Buna göre $\mathrm{H}_{0}$ "değişkenler arasında eşbütünleşme yoktur" hipotezi reddedilmektedir. Böylece değişkenler arasında uzun dönemli bir ilişki olduğu görülmektedir.

Tablo 5. Takipteki Krediler - USD Johansen Eşbütünleşme Testi (Maksimum Özdeğer)

\begin{tabular}{|c|c|c|c|c|}
\hline Hipotezler & Özdeğer & $\begin{array}{c}\text { Maksimum Özdeğer } \\
\text { İstatistiği }\end{array}$ & \%5 Kritik Değer & Olasılık Değeri \\
\hline $\mathrm{H}_{0}$ & 0.113556 & 17.53846 & 15.49471 & 0.0243 \\
\hline $\mathrm{H}_{1}$ & 0.020685 & 2.591888 & 3.841466 & 0.1074 \\
\hline
\end{tabular}

Yine Tablo 5'te $\mathrm{H}_{0}$ hipotezi maksimum özdeğer istatistiğinin \%5'lik kritik değerden büyük olduğu görülmekte ve $\mathrm{H}_{0}$ hipotezi reddedilmektedir. Buna göre takipteki krediler ile USD arasında uzun dönemli ilişki vardır.

Takipteki krediler ile USD’nin Granger nedensellik testi yapılmıştır ve sonuçlar Tablo 6'da verilmiştir.

Tablo 6. Takipteki Krediler - USD Granger Nedensellik Testi

\begin{tabular}{|c|c|c|c|c|c|}
\hline \multicolumn{2}{|c|}{ Nedensellik Yönü } & $\begin{array}{c}\text { Ki-Kare } \\
\text { Değeri }\end{array}$ & $\begin{array}{c}\text { Gecikme } \\
\text { Uzunluğu }\end{array}$ & $\begin{array}{c}\text { Olasılık } \\
\text { Değeri }\end{array}$ \\
\hline $\log ($ USD) & $\rightarrow$ & $\begin{array}{c}\text { Log(Takipteki } \\
\text { Krediler) }\end{array}$ & 21.58690 & 3 & 0.0001 \\
\hline $\begin{array}{c}\text { Log(Takipteki } \\
\text { Krediler) }\end{array}$ & $\rightarrow$ & $\log ($ USD) & 1.569467 & 3 & 0.6663 \\
\hline
\end{tabular}

Tablo 6'ya göre USD'den takipteki kredilere doğru 3. gecikme uzunluğunda nedenselliğe bakılırsa olasılık değeri $\% 5$ 'in altındadır. Takipteki kredilerden USD yönlü etkileşimde 3. gecikme uzunluğunda olasılık değeri \%5'in üstündedir. Granger nedensellik testine göre, USD, takipteki kredileri etkilerken; takipteki krediler, USD’yi etkilememektedir.

Takipteki krediler ile GBP arasında Johansen eşbütünleşme testi yapılmıştır. İz değer ve maksimum özdeğer istatistik sonuçları Tablo 7 ve Tablo 8'de verilmiştir. 
Tablo 7. Takipteki Krediler - GBP Johansen Eşbütünleşme Testi (İz Değer)

\begin{tabular}{|c|c|c|c|c|}
\hline Hipotezler & Özdeğer & İz İstatistik Değer & \%5 Kritik Değer & Olasilı Değeri \\
\hline $\mathrm{H}_{0}$ & 0.129213 & 17.72646 & 18.39771 & 0.0619 \\
\hline $\mathrm{H}_{1}$ & 0.004587 & 0.570081 & 3.841466 & 0.4502 \\
\hline
\end{tabular}

Tablo 7'ye göre $\mathrm{H}_{0}$ hipotezi iz istatistik değerinin \%5'lik kritik değerden küçük olduğu görülmektedir. Dolayısıyla iz istatistik değerine göre takipteki krediler ile GBP eşbütünleşik değildir sonucuna ulaşılmıştır.

Tablo 8. Takipteki Krediler - GBP Johansen Eşbütünleşme Testi (Maksimum Özdeğer)

\begin{tabular}{|c|c|c|c|c|}
\hline Hipotezler & Özdeğer & $\begin{array}{c}\text { Maksimum Özdeğer } \\
\text { İstatistiği }\end{array}$ & \%5 Kritik Değer & Olasllk Değeri \\
\hline $\mathrm{H}_{0}$ & 0.129213 & 17.15638 & 17.14769 & 0.0498 \\
\hline $\mathrm{H}_{1}$ & 0.004587 & 0.570081 & 3.841466 & 0.4502 \\
\hline
\end{tabular}

Tablo 8'de ise $\mathrm{H}_{0}$ maksimum özdeğer istatistiğinin \%5 kritik değerinden büyük olduğu görülmektedir. $\mathrm{Bu}$ durumda $\mathrm{H}_{0}$ hipotezi reddedilmekte ve maksimum özdeğer istatistiğine göre en az bir eşbütünleşme olduğu kabul edilmektedir.

Tablo 9. Takipteki Krediler - GBP Granger Nedensellik Testi

\begin{tabular}{|c|c|c|c|c|c|}
\hline \multicolumn{2}{|c|}{ Nedensellik Yönü } & $\begin{array}{c}\text { Ki-Kare } \\
\text { Değeri }\end{array}$ & $\begin{array}{c}\text { Gecikme } \\
\text { Uzunluğu }\end{array}$ & $\begin{array}{c}\text { Olasılık } \\
\text { Değeri }\end{array}$ \\
\hline $\log (\mathrm{GBP})$ & $\rightarrow$ & $\begin{array}{c}\text { Log(Takipteki } \\
\text { Krediler) }\end{array}$ & 20.36850 & 3 & 0.0001 \\
\hline $\begin{array}{c}\text { Log(Takipteki } \\
\text { Krediler) }\end{array}$ & $\rightarrow$ & $\log (\mathrm{GBP})$ & 2.045648 & 3 & 0.5630 \\
\hline
\end{tabular}

Takipteki krediler ve GBP değişkenleri için Granger nedensellik testi yapılmış ve Tablo 9'da gösterilmiştir. Buna göre 3. gecikme uzunluğunda GBP, takipteki kredilerin nedeni konumunda olduğu tespit edilmiştir. Tersi yönde takipteki kredilerin, GBP'nin nedeni olmadığı görülmüştür.

Son olarak takipteki krediler ile JPY arasında Johansen eşbütünleşme testi yapılmıştır. İz değer ve maksimum özdeğer istatistik sonuçları Tablo 10 ve Tablo 11'de yer verilmiştir. 
Tablo 10. Takipteki Krediler - JPY Johansen Eşbütünleşme Testi (İz Değer)

\begin{tabular}{|c|c|c|c|c|}
\hline Hipotezler & Özdeğer & İz İstatistik Değer & \%5 Kritik Değer & Olasillk Değeri \\
\hline $\mathrm{H}_{0}$ & 0.028666 & 3.612172 & 15.49471 & 0.9323 \\
\hline $\mathrm{H}_{1}$ & $4.58 \mathrm{E}-05$ & 0.005675 & 3.841466 & 0.9392 \\
\hline
\end{tabular}

Tablo 10'da takipteki krediler ile JPY arasında iz istatistik değerinin, \%5'lik kritik değerden küçük olduğunu aynı zamanda olasılık değerinin de \%5'ten büyük olduğu görülmektedir. Buna göre $\mathrm{H}_{0}$ hipotezi olan "takipteki krediler ile JPY arasında eşbütünleşme yoktur" kabul edilmektedir. Bu durumda iz istatistik değere göre takipteki krediler ile JPY arasında uzun dönemli bir ilişki yoktur.

Tablo 11. Takipteki Krediler - JPY Johansen Eşbütünleşme Testi (Maksimum Özdeğer)

\begin{tabular}{|c|c|c|c|c|}
\hline Hipotezler & Özdeğer & $\begin{array}{c}\text { Maksimum Özdeğer } \\
\text { İstatistiği }\end{array}$ & \%5 Kritik Değer & Olasıllk Değeri \\
\hline $\mathrm{H}_{0}$ & 0.028666 & 3.606497 & 14.26460 & 0.8984 \\
\hline $\mathrm{H}_{1}$ & $4.58 \mathrm{E}-05$ & 0.005675 & 3.841466 & 0.9392 \\
\hline
\end{tabular}

Tablo 11'deki maksimum özdeğer istatistiğinin yine takipteki krediler ile JPY için \%5'lik kritik değerden küçük olduğu görülmüştür. Olasılık değerinin \%5'in çok üstünde olduğu görüldüğü için yine $\mathrm{H}_{0}$ hipotezi reddedilmiştir. Bu durumda takipteki krediler ile JPY arasında kısa ve uzun dönemde bir ilişki olmadığı sonucu ortaya çıkmıştır.

Takipteki krediler ile JPY arasında Granger nedensellik ilişkisine bakılmış ve Tablo 12 'de değerler sunulmuştur.

Tablo 12. Takipteki Krediler - JPY Granger Nedensellik Testi

\begin{tabular}{|c|c|c|c|c|c|}
\hline \multicolumn{2}{|c|}{ Nedensellik Yönü } & $\begin{array}{c}\text { Ki-Kare } \\
\text { Değeri }\end{array}$ & $\begin{array}{c}\text { Gecikme } \\
\text { Uzunluğu }\end{array}$ & $\begin{array}{c}\text { Olasılık } \\
\text { Değeri }\end{array}$ \\
\hline Log(JPY) & $\rightarrow$ & $\begin{array}{c}\text { Log(Takipteki } \\
\text { Krediler) }\end{array}$ & 6.300658 & 3 & 0.0979 \\
\hline $\begin{array}{c}\text { Log(Takipteki } \\
\text { Krediler) }\end{array}$ & $\rightarrow$ & Log(JPY) & 2.189847 & 3 & 0.5340 \\
\hline
\end{tabular}

Tablo 12'de Granger nedensellik testi olasılık değerlerinin \%5'in üstünde olduğu için takipteki krediler ve JPY değişkenleri birbirlerinin nedeni konumunda değildir.

\section{SONUÇ}

Ekonomide önemli bir yere ve işleve sahip olan bankalar, kullandırdıkları kredilerin zaman zaman geri dönüşlerinde problem yaşayabilmektedir. Geri dönmeyen alacakların oranındaki artışlar, bankaları uzun dönemde etkileyebilir, bu da bankacılık sektörüne olumsuz yansıyabilir. Bu nedenle bankaların takipteki alacak hesapları makroekonomik açıdan önemli 
bir değişken haline gelmiştir. Son dönemde yapılan çalışmalarda, takipteki kredileri etkileyen birçok unsur ele alınmıştır.

Bu çalışmada takipteki krediler üzerinde etkisi olduğu düşünülen dövizdeki oynaklık incelenmiştir. Bu bağlamda Ocak 2008 - Ağustos 2018 dönemlerine ait aylık bazda bankacılık sektör bilançosundan takipteki krediler ile yine aynı dönemlere ait aylık bazda USD, GBP ve JPY döviz kurları araştırmanın konusu olmuştur. Araştırmada zaman serisi analizi yöntemleri kullanılmıştır. Öncelikle birim kök olup olmadığı ADF testi ile incelenmiş daha sonra seriler arasında eşbütünleşme ilişkisi ve nedensellik ilişkisi ortaya koyulmaya çalış1lmıştır. Buradan yola çıkarak Johansen eşbütünleşme ve Granger nedensellik testleri yapılmıştır.

Yapılan birçok çalışmada takipteki kredi değişkeni yıllık ya da çeyrek dönemler halinde alınmıştır. Bu çalışmanın diğer çalışmalardan ayrılan farkı, verilerin aylık bazda alınmış olması ve 128 aylık bir süreci kapsamasıdır.

Yapılan analizlere göre USD değişkeni ile takipteki krediler, iz değer ve maksimum öz değere göre eşbütünleşiktir. Buna göre uzun dönemde aralarında etkileşim tespit edilmiştir. Etkileşimin yönü ise USD, takipteki kredilerin nedeni konumundadır. Bu durumda USD kurundaki oynaklık zaman içinde bankaların takipteki kredilerine etki etmektedir.

GBP değişkeni için iz değer istatistiğine göre eşbütünleşik olmadığı, maksimum özdeğere göre ise uzun dönemde takipteki kredileri etkilediği saptanmıştır. Bu nedenle tam bir eşbütünleşme değeri gözlemlenmemiştir. Granger nedensellik testine göre ise GBP değişkeni, takipteki kredileri etkileyen konumdadır.

JPY değişkeni ile takipteki krediler arasında eşbütünleşme ilişkisi olmadığı iz değer ve maksimum öz değerden tespit edilmiştir. Yine Granger nedensellik testine göre JPY değişkeni ile takipteki kredilerin birbirini etkilemediği görülmüştür.

\section{KAYNAKLAR}

Abdioğlu, Nida - Aytekin, Sinan (2016), "Takipteki Kredi Oranını Etkileyen Faktörlerin Belirlenmesi: Mevduat Bankaları Üzerinde Bir Dinamik Panel Veri Uygulaması", İşletme Araştırmaları Dergisi, 8, 1, ss. 538-555.

Akgüç, Öztin (2009), “Kriz Nedeni ve Çıkış Yolları”, Muhasebe ve Finansman Dergisi, 42, ss. 6-11. Retrieved from http://dergipark.gov.tr/mufad/issue/35618/395816

Anastasiou, Dimitrious - Louri, Helen - Tsionas, Mike Efthhymios (2016), "Non-Performing Loans in the Euro Area: Are Core-Periphery Banking Markets Fragmanted?", Bank of Greece Working Paper, http://www.bankofgreece.gr/BogEkdoseis/Paper2016219.pdf (20.11.2018).

Berger, Alen N - DeYoung, Robert (1997), "Problem Loans and Cost Efficiency in Commercial Banks", Journal of Banking \& Finance, 21,6, pp. 849-870. 
Curak, Marijana - Pepur Sandra - Poposki, Klime (2013), "Determinants of Non-Performing Loans - Evidence from SoutheasternEuropean Banking Systems", Banks and Bank Systems Journal, 8, 1, pp. 45-53.

Demirel, Baki (2015), “Turkish Banking Sector Credit Risk and Modelling”, Munich Personal RePEc Archive, pp. 1-27

evds2.tcmb.gov.tr/

Genç, Erhan - Şaşmaz, Mahmut Ünsal (2016), “Takipteki Banka Kredilerinin Makroekonomik Belirleyicileri: Ticari Krediler Örneği”, Selcuk University Social Sciences Institute Journal, 36, ss. 119-129

Gökçe, Altan - Sarıtaş, Hakan (2017), "Döviz Kurlarındaki Değişmelerin Türkiye'deki Özel Sermayeli Bankaların Bilançoları Üzerine Etkileri”, Pamukkale University Journal of Social Sciences Institute/Pamukkale Üniversitesi Sosyal Bilimler Enstitüsü Dergisi, 28, ss. $1-18$

Göktaş, Pınar - Pekmezci, Aytaç - Bozkurt, Kurtuluş (2018), Ekonometrik Serilerde Uzun Dönem Eşbütünleşme ve Kısa Dönem Nedensellik İlişkileri Eviews ve STATA Uygulamaları, Gazi Kitabevi

Gujarati, Damodar N. (2003), Basic Econometrics, Third Edit, MC-Graw-Hill, İnc., USA, 1995. (Aktaran: İsmail Taş (2013), "Büyümenin Dinamiği Üzerine Bir Nedensellik Analizi”, Akademik Sosyal Araştırmalar Dergisi, 1, 1, ss. 69-86.)

Johansen, Søren (1988), "Statistical Analysis Of Cointegration Vectors”, Journal of Economic Dynamics and Control, 12, 2-3, pp, 231-254.

Keeton, William R. - Morris, Charles S. (1987), “Why Do Banks' Loan Losses Differ?”, Federal Reserve Bank of Kansas City Economy Review, 72, 5, pp. 3-21.

Klein, Nir (2013), "Non-performing Loans In CESEE: Determinants And Impact On Macroeconomic Performance", International Monetary Fund, pp. 13-72

Malik, Shahnawaz - Chaudhry, Imran Sharif - Sheikh, Muhammad Ramzan - Farooqi, Fareed Shareef (2010), "Tourism, Economic Growth and Current Account Deficit in Pakistan: Evidence from Cointegration and Causal Analysis", European Journal of Economics, Finance and Administrative Sciences, 22, pp. 21-31 (Aktaran: Esra Polat, Süleyman Günay, (2012), “Türkiye'de Turizm ve İhracat Gelirlerinin Ekonomik Büyüme Üzerindeki Etkisinin Testi: Eşbütünleşme ve Nedensellik Analizi”, Süleyman Demirel Üniversitesi Fen Bilimleri Enstitüsü Dergisi, 16, 2, ss. 204-2011)

Mileris, Ricardas (2012), "Macroeconomic determinants of loan portfolio credit risk in banks", Engineering Economics, 23, 5, pp. 496-504.

Rajan, Rajiv - Dhal, Sarat Chandra (2003), Non-performing Loans and Terms of Credit of Public Sector Banks in India: An Empirical Assessment", Reserve Bank of India Occasional Papers, 24,3, pp. 81-121. 
Sevüktekin, Mustafa - Nargeleçekenler, Mehmet (2007), Ekonometrik Zaman Serileri Aanalizi: EViews Uygulamalı, Nobel Yayın Dağıtım.

Tanınmış Yücememiş, Başak - Sözer, İnanç Asım (2011), "Bankalarda Takipteki Krediler: Türk Bankacılık Sektöründe Takipteki Kredilerin Tahminine Yönelik Bir Model Uygulaması", Finansal Araştırmalar ve Çalışmalar Dergisi, 3, 5, ss. 43-56

Tarı, Recep - Yıldırım, Durmuş Çağrı (2014), “Döviz Kuru Belirsizliğinin İhracata Etkisi: Türkiye İçin Bir Uygulama”, Yönetim ve Ekonomi: Celal Bayar Üniversitesi İktisadi ve İdari Bilimler Fakültesi Dergisi, 16, 2, ss. 95-105. Retrieved from http://dergipark.gov.tr/yonveek/issue/13691/165703

Tekşen, Ömer - Çelik, Mustafa (2018), "Kredi Türlerinin Takipteki Krediler Oranına Etkisi: Varlık Temelli Krediler Yüksek Takipteki Krediler Oranı İçin Bir Kalkan Mı?”, Muhasebe ve Finansman Dergisi, 79, ss. 95-110.

Vurur, N. Serap - Özen, Ercan (2013), “Türkiye'de Mevduat Banka Kredisi ve Ekonomik Büyüme İlişkisinin İncelenmesi”, Uşak Üniversitesi Sosyal Bilimler Dergisi, 6, 3, ss. 117-131.

www.bddk.org.tr/BultenAylik

www.swift.com/

Yağcılar, Gamze Göçmen - Demir, Semra (2015), “Türk Bankacılık Sektöründe Takipteki Kredi Oranları Üzerinde Etkili Olan Faktörlerin Belirlenmesi”, Uluslararası Alanya İşletme Fakültesi Dergisi, 7, 1, ss. 221-229

Yüksel, Serhat (2016), "Bankaların Takipteki Krediler Oranını Belirleyen Faktörler: Türkiye İçin Bir Model Önerisi”, Bankacılar Dergisi, 98, ss. 41-56. 
